NASZA DERMATOLOGIA Online OUR DERMATOLOGY Online

Source of Support: Nil

Competing Interests: None

\section{FAVRE-RACOUCHOT SYNDROME}

\section{Vikram K. Mahajan, Pushpinder S. Chauhan, Karaninder S. Mehta, Vikas Sharma}

Department of Dermatology, Venereology \& Leprosy, Dr. R.P. Govt. Medical College, Kangra (Tanda)-176001, Himachal Pradesh, India

Corresponding author: Dr. Vikram K. Mahajan

\begin{abstract}
This paper describe a typical case of Favre-Racouchot syndrome in a 70-year-old farmer. The exact pathogenesis of Favre-Racouchot syndrome remains obscure but apparently extensive exposure to sun and harsh weather is perhaps largely responsible as had been in the described case.
\end{abstract}

Key words: chronic actinic skin damage; nodular elastosis; solar elastoses; senile elastosis

\section{Introduction}

Favre-Racouchot syndrome (syn. nodular elastoidosis with cysts and comedones; elastoidosis cutanea nodularis et cystica) is a peculiar complication of solar (senile) degeneration of the skin manifesting with yellowish and atrophic skin, multiple, large, black comedones, follicular cysts, wrinkles and furrows, and yellowish nodules affecting mostly the temporo-periorbital skin of elderly individuals. Its exact pathogenesis is unclear but clinicopathologic and histochemical studies suggest that extensive exposure to sun and harsh weather is largely responsible. The pigmented skin is apparently less predisposed.

\section{Case Report}

A 70-year-old male presented with yellowish discoloration, atrophy, wrinkles and furrows, closed and open comedones with dark central plug and patulous opening, small cysts, numerous small yellowish papules and nodules over forehead, periorbital and temporal areas for over 15 years (Fig. 1). The skin over nape of neck was thickened and leathery having accentuated markings and furrows in rhomboid configurations. The patient was a farmer and native of a high altitude area. The patient refused for biopsy. After a clinical diagnosis of Favre-Racouchot syndrome, he was prescribed broad spectrum topical sunscreen creams, avoidance of undue sun exposure, and advised to follow up regularly.

\section{Discussion}

Favre-Racouchot syndrome occurs in approximately $6 \%$ individuals of $>50$ years of age and predominantly among whites [1]. Heavy smoking and radiation therapy are other reported predisposing factors [2,3]. Apart from temporo-periorbital skin, lateral neck, postauricular areas, earlobes, and forearms may rarely be involved. Although bilateral and symmetrical, one side may predominate presumably from asymmetrical sun exposure [4]. While cutis rhomboidalis nuchae is usual association, actinic keratosis, basal cell carcinoma, squamous cell carcinoma or keratoacanthoma may appear in sun-damaged skin [1]. Although histopathology is seldom required for diagnosis, it characteristically shows epidermal atrophy with significant solar elasotsis and basophilic (actinic) degeneration of the connective tissue in the upper dermis. The sebaceous glands are small in number and size or absent. The dilated pilosebaceous infundibula form loose keratin-filled comedones and follicular cysts lined with fattened epithelium [5]. Favre-Racouchot syndrome may be misdiagnosed as acne (A. vulgaris, A. comedonica or A. papulopustulosa), syringoma, and trichoepithelioma. These patients are young and readily discerning feature is presence of inflammation in acne vulgaris and absence of comedones in others. Colloid milia or sebaceous hyperplasia seen in later years of age can be differentiated by the absence of associated wrinkling, furrowing and other skin changes of Favre-Racouchot syndrome. Pseudoxanthoma elasticum or plane xanthomas are diagnosed on histology. Chemical peels, dermabrasion, comedo extraction, curettage, multi-staged surgical excision, and $\mathrm{CO} 2$ laser peel have produced variable cosmetic results $[1,6]$. Topical application of tretinoin or retinaldehyde alone or in conjunction with above procedures or oral isotretinoin $(0.05-0.1 \mathrm{mg} / \mathrm{kg})$ for 4-6 months is beneficial in some patients $[1,7]$. Retinaldehyde is less irritating than retinoic acid, significantly increases the surface area of elastic and collagen fibers, and reduces the appearance of the sun-damaged skin [7,8]. Sun protection will benefit in preventing progression. 

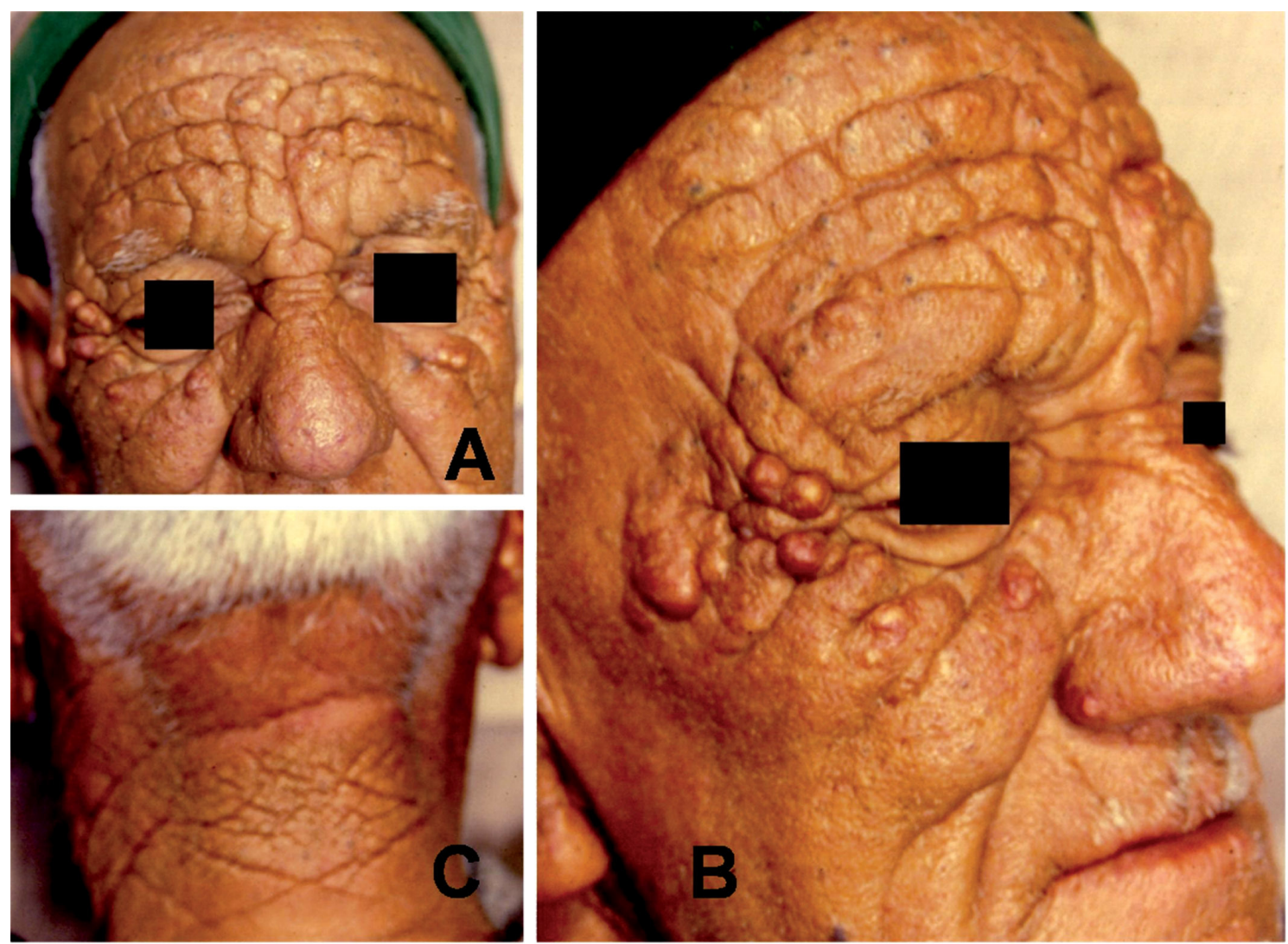
Figure 1A, B. Marked sun-damaged skin with atrophy, yellowish discoloration, yellowish
nodules, prominent wrinkles and furrows, multiple, open and closed, non-inflammatory comedones present bilaterally over forehead, periorbital and temporal areas; C. Characteristic thickened, leathery skin of neck with accentuated markings and furrows of Cutis rhomboidalis nuchae.

\section{REFERENCES}

1. Patterson WM, Fox MD, Schwartz RA: Favre-Racouchot disease. Int J Dermatol. 2004;43:167-9.

2. Keough GC, Laws RA, Elston DM: Favre-Racouchot syndrome: a case for smokers' comedones. Arch Dermatol. 1997;133:796-7.

3. Breit S, Flaig MJ, Wolff H, Plewig G: Favre-Racouchot-like disease after radiation therapy. J Am Acad Dermatol. 2003;49:117-9. 4. Stefanidou M, Ioannidou D, Tosca A: Unilateral nodular elastosis with cysts and comedones (Favre-Racouchot syndrome). Dermatology (Basel). 2001;202:270-1.

5. Sánchez-Yus E, del Río E, Simón P, Requena L, Vázquez H: The histopathology of closed and open comedones of Favre-Racouchot disease. Arch Dermatol. 1997;133:743-5.
6. Sharkey MJ, Leller RA, Grabski WJ, McCollough ML: FavreRacouchot syndrome: a combined therapeutic approach. Arch Dermatol. 1992;128:615-6.

7. Boisnic S, Branchet-Gumila MC, LeCharpentier Y, Segard C: Repair of UVA-induced elastic fiber and collagen damage by $0.05 \%$ retinaldehyde cream in an ex vivo human skin model. Dermatology (Basel). 1999;199:43-8.

8. Fluhr JW, Vienne MP, Lauze C, Dupuy P, Gehring W, Gloor M: Tolerance profile of retinol, retinaldehyde and retinoic acid under maximized and long-term clinical conditions. Dermatology (Basel). 1999;199:57-60. 